\title{
(Masih) Masalah Kesehatan Masyarakat di Indonesia
}

Masalah kesehatan masyarakat sampai saat ini masih menjadi perhatian bagi pemerintah. Kesadaran masyarakat akan pentingnya kesehatan masih rendah. Tingkat kesehatan masyarakat yang tidak merata dan sangat rendah khususnya terjadi pada masyarakat yang tinggal di pemukiman kumuh. Perilaku masyarakat yang masih tidak higienis ditambah lagi dengan tidak adanya sarana dan prasarana lingkungan yang mendukung berdampak pada kesehatan masyarakat yang tinggal pada pemukiman kumuh tersebut. Banyak masalah kesehatan masyarakat yang mungkin akan timbul akibat perilaku masyarakat dan kondisi lingkungan yang tidak memperhatikan kesehatan.

Salah satu artikel penelitian pada jurnal Kesehatan Komunitas Volume I No IV adalah tentang Telur Parasit Nematoda Usus pada Pemukiman Kurang Sehat di Kota Pekanbaru yang ditulis oleh Denai Wahyuni, Arniwita, Fachriani Putri dan Erdinal. Hasil penelitian didapatkan bahwa sebagian besar rumah (76,7\%) di lingkungan pemukiman yang kurang sehat di Kota Pekanbaru, mempunyai kondisi drainase yang tergenang. Ditemukan adanya telur dari dua jenis parasit Nematoda usus di tanah di lingkungan pemukiman kurang sehat yaitu A. Lumbricoides dan T. Trichiura pada semua drainase.

Kondisi lingkungan dengan air yang tergenang, juga merupakan risiko untuk terjangkitnya berbagai penyakit akibat lingkungan yang tidak sehat, salah satunya adalah penyakit Demam Berdarah Dengue (DBD). Penelitian yang dilakukan oleh Jasrida Yunita, Mitra dan Herlina Susmaneli, diperoleh hasil bahwa ada hubungan yang signifikan antara perilaku masyararakat dan Kondisi lingkungan dengan kejadian DBD. Kebiasaan masyarakat yang menggantung pakaian di rumahnya dan Adanya jentik nyamuk pada tempattempat air tergenang merupakan faktor resiko yang paling dominan berpengaruh terhadap kejadian DBD.

Masalah anemia pada anak sekolah juga masih menjadi masalah kesehatan masyarakat di Indonesia. Penelitan yang dilakukan oleh Sri Desfita yang mengangkat tema tentang Prevalensi anemia pada anak sekolah, Status gizi dan kebiasaan makan pagi makan pagi pada murid SD, didapatkan hasil bahwa prevelensi anemia pada murid SD adalah sebesar $34,2 \%$, prevalensi gizi kurang sebesar $15,2 \%$ dan masih banyak murid SD yang tidak biasa makan pagi.
Kompleksnya masalah kesehatan menjadi perhatian bagi pemerintah. Perlu adanya perencanaan dari pemerintah untuk mengatasi berbagai masalah kesehatan tersebut. Perencanaan kesehatan adalah sebuah proses untuk merumuskan masalah-masalah kesehatan yang berkembang di masyarakat, menentukan kebutuhan dan sumber daya yang tersedia, menetapkan tujuan program yang paling pokok dan menyusun langkah-langkah praktis untuk mencapai tujuan yang telah ditetapkan. Keberhasilan program salah satunya ditentukan oleh perencanaan yang baik. Penelitian yang dilakukan oleh Jasrida Yunita tentang Proses perencanaan tahunan dinas kesehatan kabupaten Padang Pariaman, diperoleh hasil bahwa Alur perencanaan di Dinas Kesehatan Kabupaten Padang Pariaman belum mengikuti alur ataupun langkah-langkah perencanaan terpadu. Selain itu koordinasi lintas program maupun sektor sudah berjalan tetapi dalam pelaksanaannya masih belum maksimal.

Belum maksimalnya upaya yang dilakukan oleh pemerintah menyebabkan masalah kesehatan masyarakat masih tetap ada. Selain itu perilaku masyarakat yang belum sepenuhnya menerapkan Perilaku Hidup Bersih dan Sehat (PHBS) merupakan faktor resiko untuk terjadinya berbagai masalah kesehatan masyarakat di Indonesia. 